Journal for Social Action in Counseling and Psychology

Volume 4, Number 2 Fall 2012

\title{
Revolutionary Leadership: From Paulo Freire to the Occupy Movement
}

\author{
Mary Watkins
}

Pacifica Graduate Institute

\begin{abstract}
All over the world, individuals in groups are attempting to occupy their "Commons." In an era of gross income and power divides, this reclamation must go hand-in-hand with a process of psychic and interpersonal decolonization, where the received hierarchical roles and leadership practices we have inherited are disrupted and thrown into question. Beginning with Paulo Freire's ideas on revolutionary leadership, and continuing to the principles and practices emerging in the OCCUPY movement, the author focuses on the consensus process and on horizontalism (horizontalidad). To aid in the radical transformation of the structures of oppression, counselors and other dialogically-skilled individuals are needed to help facilitate shared leadership, inclusive dialogue, conflict transformation, and consensus decision-making.
\end{abstract}

Keywords. reclaiming the commons, consensus, revolutionary leadership, horizontalism (horizontalidad), revolution, dialogue, communities of resistance, cultural worker, limit act, OCCUPY movement

\section{Recovering the Commons}

Mistrust, disappointment, disillusionment, and anger mark our current relationship to leaders. The exercise of excess power, including violence, to satisfy rapacious desires for further power, prestige, privilege, and wealth have bled away the lifeblood - the needed nutrients for a decent life - from the majorities. Lies, manipulation, corruption, and deceit have betrayed and marred our hopes for forms of leadership for the common good. The raping of resources, including the labor of human beings, from one place and its inhabitants for the benefit of another much smaller set of people in another place is familiar to us from colonialism. But now it is threatening the sheer viability of the entire planet: people, animals, rivers, oceans, the deep bowels of the earth, the soil itself, the air we breathe. These rapes have led to dizzying economic divides, now publicized by the Occupy Movement's discourse of "the $1 \%$ and the 99\%." 
Journal for Social Action in Counseling and Psychology

It is no secret that stark income divides contribute to poor health, diminished life span, increased violence, paucity of community life, and increased mental illness (Wilkinson \& Pickett, 2009). As those among us lose access to education, medical care, employment, and adequate shelter and food, societal demoralization sets in. We find ourselves and/or those nearby us increasingly living in what João Biehl (2005) calls "'zones of abandonment,' which 'accelerate the death of the unwanted' through a form of economic Darwinism 'that authorizes the lives of some while disallowing the lives of others"' (Giroux, 2012). ii

For many, it no longer seems possible that reforms within our existing systems will adequately respond to and redress the growing misery wrought by the greed of immoral leadership and its attendant wars and violence that secure a perilous and widening income abyss. Hannah Arendt (1971) defined revolutionary times as those that reach a point where we have to admit that the body politic can no longer be restored to its initial integrity and that an "entirely unexpected and very different task of constituting something entirely new" is upon us (p. 207). iii

There are diverse goals for leadership that lead to quite disparate descriptions of the necessary qualities of leaders. Here I am concerned with leadership that aids in healing profound income divides and the vertical relations of power that create and protect them. I am concerned with leadership that enables us to "recover the Commons." This is a term that is invoked in the Occupy movement and its sister revolutions worldwide. To what does it refer, and what new concepts and rationalities does it require of us (Chomsky, as cited by Esteva, 2009)?

Poet and environmental activist Gary Snyder (1990) describes the commons ${ }^{\mathrm{iv}}$ as an "ancient mode of both protecting and managing the wilds of self-governing regions" (p. 32). The land belonged to the local community, and was both used and cared for to promote the common good. Snyder says, "[t]he commons is a level of organization of human society that includes the nonhuman. The level above the local is the bioregion" (p. 40). When a piece of land or water was considered part of the commons, it did not mean that everyone could take from the common resource as much as he or she wanted. Access was regulated so that the commons was protected from the excesses of individual exploitation. Being a part of the commons involved mutual obligations of stewardship: obligations between people, as well as between people and the local natural system.

The practice of the commons in England was disrupted during the fifteenth to nineteenth centuries by the enclosure movement. Land was stolen from community stewardship using John Locke's treatise on property to justify it. Locke linked individual freedom with "the freedom to own, through labor, the land, forests, and rivers" (Shiva, 2002, pp. 25-26). Village-held land was fenced off and privatized, disrupting sustainable, communal agriculture. In the $18^{\text {th }}$ century many people had to leave the countryside for the urban areas because they could no longer sustain themselves through their relationship to the land. These rural homeless were the first members of the industrial working class. ${ }^{\vee}$

Throughout the world the seizure of "the commons" by central governments, corporations, and individual entrepreneurs has led to collapses of local cultures-human and animal, the loss of sustainable farming practices, and the degradation of the soil, forests, and water. Snyder (1990) says "it is clear, the loss of a local commons heralds the end of self-sufficiency and signals the doom of the vernacular culture of the region" (p. 39). He and many others call for a 
Journal for Social Action in Counseling and Psychology

recovery of the commons, "people's direct involvement in sharing (in being) the web of the wild world" (Snyder, 1990, p. 39).

The logic and the ethics of the commons are different from that of the market or the state. Vandana Shiva (2002), Indian eco-feminist philosopher and activist, in speaking of water rights says they are natural rights that "do not originate with the state; they evolve out of a given ecological context of human existence" (p. 20). When this is not honored, the poor are excluded from their share of water, the water of whole regions is siphoned off for excess financial gain elsewhere, denuding the ecosystem which deprives the people, creatures, and plants living there of a necessary resource for thriving and surviving. Shiva suggests several principles underpinning water democracy in the context of recovering the commons: 1 ) including developing a sensitivity to how we experience a mutuality with nature in which we know we owe our own well-being to it; 2) that all species and ecosystems have rights to existence; 3) that we have a duty to ensure our actions do not cause harm; 4) that selling natural resources for profit "violates our inherent right to nature's gifts and denies the poor of their rights;" 5) that we have "a duty to conserve and use water sustainably, within ecological and just limits," that "no one has the right to overuse, abuse, waste, or pollute water" (pp. 3536). To do otherwise is to disrupt the gift from nature that water is. It is to act against the sacred. "Protection of vital resources...demands a recovery of the sacred and a recovery of the commons" (Shiva, 2002, p. 138).

In Paulo Freire's language, to recover a commons is a "limit act" in the face of a "limit situation." He uses Alvaro Veira Pinto's definition of a limit situation as not "the impassable boundaries where all possibilities end, but the real boundaries where all possibilities begin; [these boundaries are not] the frontier which separates being from nothingness, but the frontier which separates being from being more" (Freire, 1989, p. 99). Recovery of commons requires participatory democracy and cooperative community participation, where people become sensitivized to each other's genuine needs and the needs of the natural world.

The Commons Movement attempts to support local communities that still have commons while encouraging other local communities to develop commons, replacing corporate and privatized control with local communal ownership. It uses the term "commons" to refer not only to shared ownership and stewardship of resources such as land and water, but of knowledge, language, spiritualities, information, and community infrastructure. Sadly, even government is named as a lost Commons, corrupted by the money of corporate lobbying or hijacked by dictators. The loss of the Commons is inseparable from the reign of relationships marked by domination, oppression, violence, exploitation, and usurpation. To recover the Commons we must re-orient ourselves to one another.

In the Occupy movement the Commons was symbolized by the encampments in public spaces, by the taking back of the right to occupy our cities and towns' public squares. These occupations symbolized other needed occupations, such as the need to occupy the insufficiently regulated banking and financial systems, to help homeowners occupy their homes foreclosed not due to their own shortcomings but to the rigging of the mortgage market and illegal foreclosure practices, the occupation of our educational system so that young people do not exchange formal education for debtor status in an economy that is failing through no fault of their own, and the occupation of our food system so that food security can be achieved. 
Many of those who occupied the encampments felt a deep sense of loss and subsequent mourning when the camps were forcibly destroyed by orchestrated efforts of the state. While not entirely utopic spaces, they had become, in Mary Belenky's (1996) words, "public homeplaces." Occupiers had co-created a rare sense of solidarity, of shared meanings and aspirations, of relationships marked largely by inclusivity, mutuality, generosity, and common purpose for the good of the many. Sharing food that was available to any who needed it: setting up medical services, counseling and listening stations; establishing a common library; creating security forces armed with mediation techniques to defuse conflicts; establishing teachins for education and dialogue; and creating self-governance built on transparency, dialogue, and consensus were inspirational beyond people's wildest dreams. Insofar as these practices did pose an alternative to pernicious aspects of neoliberal globalization, they were seen by some of the $1 \%$ as posing a dire threat, as needing to be destroyed. It is now up to our ingenuity to carry on these practices without the support of stable physical places.

Snyder (1990) says that "a place on earth is a mosaic within larger mosaics-the land is all small places, all precise tiny realms replicating larger and smaller patterns" (p. 29). Each of the encampments was one such small mosaic where participatory democratic principles were being practiced with the hope of their extension into the larger societal mosaics of which we are each a part. To restore the commons and to create new commons we must attend to the creation of spaces where human relations can be regenerated. The same forces that have destroyed the commons, have destroyed through violence, lies, deceit, corruption and exploitation the delicate interdependent ties between peoples, within families, and those most fragile membranes of exchange in the mind where we metabolize differences and recover psychic space for multiplicity, contradiction, ambiguity and the unthought.

Gustavo Esteva, deprofessionalized Mexican intellectual and activist, names intercultural dialogue as the main challenge of the $21^{\text {st }}$ century, and enjoins us to create "cultural commons," where we learn how to engage with the "radical otherness of the Other" (2009). He urges us to promote "common-ism", not communism (2009). The former goes beyond the nation-state, beyond socialism and communism. Instead of waiting for the utopia over there, he says, we can create it in our own place. Once freed from the discourse on socialism and capitalism, he says, there can be "an explosion of imagination" (2009). Unlike fundamentalistminded communities that close off their borders completely, the localism he is advocating develops inter-relations with other commons that are also learning how to live sustainably and vibrantly with one another.

Such commons are based on hospitality, instead of development. Esteva names three pillars for their recovery of the commons: friendship, hope, and surprise. He values the coming together of 2 and 3 people, and the gathering of 200 and 300, 2000 and 3000, 2 and 3 million.

Snyder (1990) offers his advice about where to start in this recovery of the commons: "The sum of a field's forces becomes what we call very loosely the 'spirit of the place.' To know the spirit of a place is to realize that you are a part of a part and that the whole is made of parts, each of which is whole. You start with the part you are whole in" (p. 41).

This beautiful passage challenges us to focus on those places marked by spaciousness, where our totality is welcomed. In The Raft is Not the Shore, Thich Nhat Hanh and Daniel Berrigan (2001) call such places communities of resistance. By "resistance" they mean "opposition to 
being invaded, occupied, assaulted, and destroyed by the system" (p. 129). The purpose of resistance, here, is to seek the healing of oneself and one's community in order to be able to see clearly. Such local efforts of renewal are crucial to the regeneration of solidarity and the work of transformation that is before us.

Thich Nhat Hanh (2001) says, "I think that communities of resistance should be places where people can return to themselves more easily, where the conditions are such that they can heal themselves and recover their wholeness" (p. 129). This was clearly happening in the Occupy encampments and continues in Occupy's many working groups and general assemblies. Amid and in opposition to violence and injustice, it is necessary for people to join together to create communities where justice and peace on a small scale are possible. This allows those who participate as well as those who visit to experience that life is possible, that a future is possible. Such communities resist the dehumanizing forces present in the dominant culture. From maroon communities during slavery in the Americas, to Sarvodaya movement village gatherings in Sri Lanka, to women's tree planting groups in Kenya's Green Belt Movement, to Occupy's encampments, such communities of resistance attempt to birth locally more humane ways of being together. From this base it becomes possible to network with others and to slowly address the larger societal structures that create violence and injustice.

Snyder (1990) quotes a Tlingit elder, Austin Hammond, who described empires and civilizations as glaciers, saying that when these alien forces advance, as in industrial civilization, "settled people can wait it out" (p. 42). To do so one must be part of a community of resistance and have access to the long and deep time in which changes accrue and can manifest true transformative potentialities.

In addition to communities of resistance, to restore the commons we must restore and create sites of reconciliation (Watkins \& Shulman, 2008), where co-existence across difference can thrive. As the customary borders of cultural groups burst and resources are increasingly contested, the psychological and communal dialogical capacities need to be in place to mediate conflicting claims, and to see past such conflict into the common aims that could be satisfied by the creation of interlinked commons.

The recovery of the commons is a form of alterglobalization - an alternative to exploitative forms of globalization. It requires a corollary recovery and creation of dialogical practices that mend the fabric of community. Esteva suggests our unit of understanding be the commons, and not the person. To meet the possibility of the commons, people - you and I - must create psychic and social spaces where we can unfurl ourselves, where our bodily being can recuperate a sense of well-being and vitality, where we can unfold our thoughts, images, and desires with one another, and listen to other people's to find modes of thinking and acting in solidarity with one another for the sake of creating sustainable ways of living. These are the psychological and relational capacities that must be built to re-claim the Commons.

My task here is to offer thoughts on leadership in this context, in the context of re-seizing the Commons in an era of gross income disparities. What kinds of leadership will support people's re-occupation of the "Commons"? What do you see? As you will come to see, in order to arrive at what I will propose are the qualities of a revolutionary leader, we must back away from some of the taken-for-granted ideas we hold of what a leader does and of how power is held and exercised. 


\section{Freire on Revolutionary Leadership}

While in the midst of practicing as a clinical psychologist informed by archetypal psychology, I discovered the work of Paulo Freire, the Brazilian pedagogist who radically critiqued education that disempowers students and that naturalizes dominant ideologies that are not in the people's best interests. He proposed in its lieu a pedagogy not for the oppressed, imposed on them through systems of power, but a pedagogy of the oppressed. He envisioned education as a potentially liberatory activity, helping people decode together their daily experiences so that they can understand how everyday reality is structured, thereby better preparing themselves to intervene in it to create needed transformations.

In his childhood in northeast Brazil, Freire had the experience of first being solidly in the middle class and then of falling out of it suddenly as shockwaves of the United States' depression struck the Brazilian economy. Unable to concentrate in school due to his hunger, he forged the intention as a boy to grow up and work on issues of hunger. After a single case as a lawyer, he turned to education and the problem of vast illiteracy in the northeast of Brazil. He connected the plight of the hungry poor to their divestiture by elites from education, and linked literal hunger to hunger to make sense of the world around one, hunger to learn to read, to decode the situation we find ourselves in, and to write together the future.

He began his teaching in what he would soon term a "banking mode," educating people about their problems and proposing solutions to them. One night he returned home with his wife, Elsa, from a public gathering where he had lectured. He felt he had done a good job, but noticed his wife appeared upset with him. When asked why, she critiqued his teaching, faulting him for providing both questions and answers. Freire realized that his performance of his proficiency communicated a lack of trust in the others in the room. Without a practiced humility, he could not learn from them about the situations they found themselves in, their understandings of the causes of their lived reality of oppression, and their hopes for transforming their situation of being dominated. Some years later, Freire was able to say: "Those who steal the words of others develop a deep doubt in the abilities of the others and consider them incompetent. Each time they say their word without hearing the word of those whom they have forbidden to speak, they grow more accustomed to power and acquire a taste for guiding, ordering, and commanding" (Freire, 1989, p. 134).

In 1961, he was asked to initiate a literacy program that would involve teaching five million people previously denied education by institutions of neocolonialism. As in the United States where it was also forbidden to teach slaves how to read and write, such deprivation was used in Northeast Brazil to disempower the masses and make claims of their inferiority easier. Such claims then rationalized abuses of laborers, as they do in the United States. The majority were consigned to conditions of poverty, malnutrition, and illness in order that a few in power could profit.

In 1962 Freire directed a project where 300 rural farmworkers were taught to read and write in 45 days. In 1963 President Goulart invited Freire to rethink Brazil's approach to literacy and to coordinate the National Literacy Plan. He and his colleagues set up 200,000 cultural circles to host the emergence into literacy of two million Brazilians. A coup d'etat replaced Goulart with a repressive military government. Shortly after the coup, Freire was imprisoned for 70 days, and 
was called an "international subversive," a "traitor to Christ and the Brazilian people," of trying to make Brazil a Bolshevik country (Gadotti, 1994, p. 35).

While in prison Freire grasped more deeply the essential connections between education and politics. The landowners had understood that through education the peasants would become aware of their social situation and begin to organize to improve their situation (Gadotti, 1994, 33). He was exiled and from 1964-69 he worked on issues of agrarian reform, organizing peasants and small farmers, and consulting on literacy issues in Bolivia and Chile. He relished studying his method in other contexts, claiming that a particular locale had to develop its own generative themes and strategies. During his time in Chile he was able to complete Pedagogy of the Oppressed, first published in 1968 then translated into dozens of languages. It was banned in most Latin American countries as well as the Iberian Peninsula during the years of his exile. His method has affected critical dialogical practice on all continents.

By dialogue Freire was not referring to a technique. He asserted that "dialogue characterizes an epistemological relationship ... dialogue is a way of knowing." "I engage in dialogue because I recognize the social and not merely individualistic character of the process of knowing. In this sense, dialogue presents itself as an indispensable component of the process of both learning and knowing" (Freire and Macedo, 1995, p. 379).

Freire was insistent that we be careful not to assume that our dream is the dream of the people. The methodology he developed to avoid this was one of asking generative questions that provoke insight, deep listening to others, shared critical reflection, prophetic imagining, and experiments together in action to transform aspects of reality from undesirable state to states desired by a consensus of people. We see aspects of his method in action in the Occupy Movement.

This repeating cycle of critical reflection, itself an action, and the actions that emerge from this reflection can be found enacted all over the world today, where people oppressed by their circumstances are working together to transform their worlds. Together members of a group move from conscientization and annunciation - of developing together critical consciousness and imagining together what is commonly desired - and then moving into transforming actions forged in solidarity.

The more schooling most of us receive, the more we are taught to identify with being experts and "leaders." Freirean practice helps us to disidentify from the injunctions of expertism common to competitive and individualistic cultures, and to explore and enact dialogical methodologies that help people think together. His work is at the heart of my own theorizing, community practice, and participatory research. So it is here I will begin, in Freire's own work on revolutionary leadership.

Unless people see themselves and are seen by others as capable of critical reflection, creative imagination, and transformative action, their thinking and action will be co-opted and manipulated by leaders of the elites who esteem their own thoughts and self-serving goals more than those of others. Struggles engaged in will not be truly revolutionary, but domination in a different set of clothes. Liberation requires that my action and reflection be placed alongside that of others, and put into creative dialogue with theirs. Freire says that, "Manipulation, sloganizing, 'depositing,' regimentation, and prescription cannot be components 
of revolutionary praxis, precisely because they are the components of the praxis of domination" (2008, p. 126). Revolutionary praxis is at heart dialogical practice, for it is only in engaging in dialogue that those who have been subjugated can claim their role as subjects of their own transformation. He asserts that "[d]ialogue with the people is radically necessary to every authentic revolution. This is what makes a revolution as distinguished from a military coup.... Sooner or later, a true revolution must initiate a courageous dialogue with the people. Its very legitimacy lies in that dialogue.... The earlier dialogue begins, the more truly revolutionary the movement will be" (p. 128). "[D]ialogue is the essence of revolutionary action" (p. 135). One does not deny dialogue to accomplish a revolution, thinking that after the struggle, dialogue will begin. The very foundation of authentic revolution is dialogue. Revolution requires "actors in intercommunication," as we are "essentially communicative creatures" (pp. 128-129). Freire remarks on the courage it takes for leaders to be in "humble, loving, and courageous encounter with the people" (p. 129). In authentic revolution leaders do not appoint themselves, they are authenticated through their praxis by the people.

He argues that the "educational, dialogical quality of revolution, which makes it a 'cultural revolution' as well, must be present in all its stages" (p. 137), and that this helps to safeguard the revolution from becoming reactionary. We see presently in our own culture enormous resources deployed to create a culture of entertainment, partaken alone or with one or two others. Being entertained through consumerism of products and media, one is lulled into passivity, and deprived of opportunities for developing critical thinking and engagement in dialogue. The status quo is not problematized, but presented as static and fixed. The use of the imagination is hijacked, deployed away from rehearsing for other ways of being, and invested instead in disrupting any resistance to the status quo.

Dialogue is not used for the sake of the revolution. It is the revolution. Struggle that preempts dialogue is counter-revolutionary. The lofty goals of revolution must begin in our relations with one another, in our family, our workplace, our community, in conversation with neighbors and members of groups from whom we are estranged. There is a great temptation to skip over dialogue for the presumable sake of the revolution. But there is no shortcut. A struggle that skips over dialogue, failing to make it a foundational building block, becomes another oppressive reality in which people are deprived of exercising their own subjecthood in which their capacity to create and to transform the world is rooted.

Freire is clear that antidialogue is oppression and is necessary to the maintenance of oppression. The oppressors deposit myths into the minds of the people, myths that mislead, confuse, obscure, and miseducate. "We have liberated Iraq." "This is a crisis, and requires a temporary curtailing of human rights for the sake of security." "Banking regulation is bad for the economy and hurts everyone." "Voting is the principle responsibility of a citizen." "Capitalism is necessary for democracy." "Government has the common good at the heart of its interest." Those engaged in critical dialogue wrestle with these myths in an attempt to see reality more clearly, to determine who and what the myths serve, and to present alternative ways of understanding and of living with one another.

None of this is possible without dialogue, that messy process that challenges us to look directly into the partiality and wrong-headedness of our own thoughts. It is a process that requires our patience to temper our thoughts by hearing out those who hold widely differing perspectives. It 
Journal for Social Action in Counseling and Psychology

requires us to listen most closely to those we have cast as our enemies, as they are most often, as Gene Knudsen Hoffman (1997) taught us, "those whose stories we have not yet heard."

Freire's work helps us delineate some of the essential qualities of revolutionary leaders whose work is the recovery of the commons.

- A revolutionary leader holds the common good of people, animals, and earth as her highest aim.

- A revolutionary leader takes care to craft generative questions. This empowers others to develop their own understandings.

- A revolutionary leader listens deeply. This allows her to hear others' understandings of their own dilemmas and dreams.

- A revolutionary leader is inclusive; he learns how to help each member of a group make a contribution to the understanding at hand. He does not disempower through enacting a banking model of education.

- A revolutionary leader has faith in the people, in their capacity to reflect, to create new knowledge, and to pose imaginative solutions that will inform their actions together.

- $\quad$ The revolutionary leader knows that when lived realities are presented as fixed and static, that they are being construed as such by people for certain purposes. When these purposes are for the sake of exploitation and oppression, he knows he must work to demystify - to see through - the situation he finds himself in, penetrating and dispelling the ideologies that have gone unquestioned.

- Having listened intently to people's experiences, a revolutionary leader must have the courage to announce from one's perspective what characterizes one's epoch, aware that these very words may risk one's security, and, at times, even one's life. ${ }^{\mathrm{vi}}$

- $\quad$ Leadership-for-the-sake-of-the-commons and courage need to be linked.

- The revolutionary leader knows the power of imagination ${ }^{\text {vii }}$ to exceed the known, and she invites others to look past oppressive realities to dream of other ways to structure our relations.

- A revolutionary leader has integrity. There is congruency between his vision and his manner of being, his practices, and his goals. The work he does and the manner in which he pursues it are consonant with his deepest understandings of what is needed and what is important in the world that we share.

- A revolutionary leader creates-with-others in the present, the kind of world they want to see more broadly.

- A revolutionary leader has clarity about his own social location and its potential limits on his understanding. He does not seek for others to replicate his exact understandings and methods. He is not interested in the universalizing of what he knows, but in fostering the creative generativity of all people in their local circumstances.

Gene Sharp (2005), whose study of nonviolent revolutionary struggle has been used around the world and most recently by the Arab Spring movements, defines leadership qualities for nonviolent revolutionaries that are consistent with Freire's insights. In some nonviolent struggles it is: 
difficult or impossible at various stages to identify who the leaders [are], if indeed there [are] any, except locally and temporarily. Analysis is required of the possibility that wide diffusion of knowledge of nonviolent struggle, including its dynamics and requirements, may greatly reduce the need for identifiable leadership in actual struggles ...

Certain qualities should be taken into account when selecting leaders. Leaders should set the example, know their people and look out for their welfare, be technically and tactically proficient, seek out and accept responsibility, let others get credit for success, observe loyalty to superiors and subordinates, know the opponents, learn from the experience of one's own group and others as well, maximize and challenge the abilities of subordinates, and pick the right people for the right positions.

Very importantly, the leaders should either have significant knowledge of nonviolent struggle and be capable of wise strategic planning or have the judgment and humility to rely on other persons with those qualities for strategic direction. (pp. 478-479)

To join the conversation on "leadership" I borrowed Freire's term "revolutionary leadership," but it is possible that the language of leadership will mislead us. Freire called the revolutionary leader an "animator," one responsible for helping a group decode their reality, and thus for problem-posing and the asking of generative questions. African-American women leaders from the Deep South, such as Ella Baker, call such a revolutionary leader a "cultural worker." Cultural workers are committed to developmentally oriented leadership that has as its aim creating environments in which people can grow in their thinking with one another, and are affirmed in their qualities and strengths (Belenky, 1996, p. 414). Scholar-activist Barbara Omolade understands this kind of developmentally-oriented leadership as "originating in African tribal societies organized around democratic-consensus processes" (Belenky, 1996. p. 414).

Others use the word "facilitator"; some use the term "maternal leadership," as the revolutionary leader is "devoted to promoting the development of the most vulnerable members of society" (Belenky, 1996, p. 415). She is likened to a midwife, to one who can listen others into speech. She is seen as a bridge between people and communities. Patricia Hill Collins (2000) describes her "as a community othermother." An othermother in African American communities is one who treats those who are unrelated biologically as members of his or her own family. Such an othermother expresses an ethic of caring and personal accountability which is intended to provide uplift, and act as an antidote to domination and control (Collins, 2000).

\section{Facilitating Leadership and the OCCUPY Movement}

Last fall, while living in New York City, I visited Zuccotti Park regularly, and after the police's destruction of the Occupiers' encampment, I visited The Atrium, a large space where Occupy working groups convene each day. Occupy is challenging casino capitalism, and, in doing so, forming resistance to the most powerful influences on the planet today. How this is being done is worthy of separate discussion. I, however, am going to drop below this level of action, and focus on the processes by which Occupy is addressing proposals for action. In New York City I studied how facilitation occurs in both the General Assembly and in the working groups. I engaged in facilitation trainings, and was part of discussions where facilitation occurred. I also witnessed conversations about breakdowns in communication and struggles to match dialogical processes to the goals of particular sessions. 
Occupy has been critiqued as a leaderless movement that will come to little if leaders do not emerge, and if platforms are not crafted and widely published. The Editorial Board of the Northern Star (retrieved, 4/14/12) complains that

This basis of organization is leading the movement nowhere. We understand the protesters are disillusioned by political leaders because they account for a portion of the 1 percent. However, this horizontal structure of leadership lacks organization, and without organization, they will never get anything done....We realize the horizontal structure of the Occupy Wall Street movement was a popular mechanism used to draw in supporters, but this structure is unrealistic in the long term. ... This movement desperately needs a leader who can clearly articulate the group's goals.

What is missed in such a critique is what is being accomplished by being a "leaderful" movement, that is, by being inclusive of the emerging leadership of all members. By focusing on the practice of participatory democracy, Occupiers are bringing into existence-amongst themselves and for the world to see - an alternative to the in-name-only democracy we suffer under. Discussions are open. The workings of the movement are intentionally transparent. Notes of working groups are published on the internet for any interested party to see. There will not need to be a Wikileak for the Occupy movement.

Training is given to members about the consensus process, its importance, and how to engage in it. Consensus decision-making processes have a rich history, with intermingling streams from key tributaries such as many indigenous groups, Quakers, Mennonites, anarchists, feminists, workers, and neighborhood councils. Most Occupiers do not think of themselves as anarchists, and yet their praxis and norms draw heavily from various strands of anarchism, particularly in their emphasis on mutual aid, horizontalism, consensus, and direct action (Graeber, 2004). Through direct action a group is able to show possible solutions to problems that are being confronted. For instance, some of the Occupy encampments worked to provide safe sleeping space and food to the homeless, others worked to prevent home evictions through group occupation. Undoubtedly, most Occupiers are not educated in the historical roots of consensus decision-making. In these cases, the external actions of wiggling fingers or taking stack may appear merely procedural, rather than the expression of revolutionary principles. Until enough Occupiers deeply understand the revolutionary logic of consensus process, misunderstandings, frustrations, and impatience can disrupt meetings and undermine the building of needed solidarities.

Psychologically-minded people, schooled in the history of consensus building, as well as in the practicalities of facilitating the on-the-ground practice, are needed to ally with Occupiers. They are needed as well to create space for interpersonal tensions to be untangled and sorted through, so that they do not disable a group. The sooner children and adults can be tutored in participatory democracy, its values and its praxis, the sooner we will begin to have a population that is able to move into settings where horizontalism is valued and practiced. As anarchists and others have known and articulated, it is crucially important that we live and taste the alternative world our principles are dreamt for, even in small and protected settings.

Occupiers are taught a number of hand signals that help discussions to proceed in an inclusive and thoughtful manner. In Occupy Wall Street the governance structure that has evolved is for the General Assembly (GA) to decide broad issues. There are many working groups that meet 
regularly and contribute a representative to the Spokescouncil. The "spokescouncil" handles day-to-day operations.

I want to focus on the leadership for facilitated dialogue in OCCUPY. The point of facilitation is to create a space where many thoughts can be creatively and critically considered. The facilitator engages in multipartiality for the sake of the process. His or her own personal opinion about the proposal under consideration is bracketed. The highest goal is participatory democracy and the role of the facilitator is to create and safeguard the space in which this is possible.

When a person or group has a proposal to bring to the GA, it is published on the website at least 24 hours before the GA. The proposer gives a several sentence presentation that flushes out the proposal in terms of why it is needed, etc. This cuts down on the need for clarifying questions. The facilitator "opens stack," asking if anyone has questions about the proposal. A co-facilitating stacktaker writes down the first names of the people who desire to speak, and then they proceed in order with one exception. Taking stack helps more people to enter into the dialogue and discernment. An innovation to help ensure that those who are traditionally marginalized - such as women and "minorities" - have a chance to speak more often is the use of progressive stack.

"Progressive stack" allows you to put people in front who haven't spoken yet. The facilitator is mindful of "stack jumpers," individuals who present themselves as asking a clarifying question, when they are actually just trying to speak and are not wanting to wait to get on stack.

As clarifying questions wind down, the facilitator warns that questions will be closed after the next question, and that the discussion will move to clarifications. After the proposal is understood, the assembly moves to make a space where concerns can be heard. The facilitator takes a "temperature check" to see if the group is moving toward consensus. If there seems to be more concerns, one can go back to taking stack. The facilitator can assess and announce: "We are moving toward consensus. Are there any blocks?" If so, each person who is blocking has a chance to speak on his or her block. A block is a serious concern with the proposal. Participants are warned that is should be considered "a once in a life time thing," not to be used casually. This is an important part of the process. When a group goes forward over and against others' deep objections, the outcome desired is often subverted. Also the group is deprived of the potential wisdom and ethical discernment that may be ingredient to the block. One person's voicing of the reasons behind his or her block can create greater ethical sensitivity in other members, leading to a better decision in the long run. ${ }^{\text {viii }}$ This may lead to an amendment being proposed that will help lay the way for the block to be removed. If after amendments have been forged, there are remaining blocks, the facilitator moves to see if a modified consensus has been reached. If a proposal achieves $90 \%$ agreement, while still having one or more blocks, the proposal is carried, while respecting the block(s). If it is less than $90 \%$, those with concerns meet with those who crafted proposal to possibly bring it back to the floor in a revised state.

The NYGA began with a $75 \%$ modified consensus. Then they wanted to be stricter and have it closer to ideal consensus. We can each consent to something without it being that meaningful to us or feeling all that good about it. The hand signal of holding one's fingers down is still consent. If there is a lot of this lukewarm or cool reception, it should be picked up early in the 
temperature check. Participants learn that they can stand aside, conveying "I disagree with this but I am not going to block it." Once a proposal is tabled, participants are encouraged to stop talking about it, and to go on to the next item of business. The following is a summary of hand signals used in both GA's and working groups (Retrieved 5/25/12, from http://en.wikipedia.org/wiki/Occupy_hand_signals\#cite_note-SF-9):

- Wiggling their fingers at eye-level (imagine playing a tiny air guitar) to say "I'm confused."

- $\quad$ "Up twinkles or simply twinkles are both hands raised with fingers pointing up and being wiggled. Twinkles indicate agreement with what is being said.

- Flat hands means that you are not sure, not for, or not against. One may be asked to clarify one's position.

- Down twinkles are arms raised but showing the back of both hands with fingers pointing down and wiggling. Down twinkles indicate disagreement with what is being said. One will be asked by the facilitator to clarify one's objection. In Occupy Boston (possibly other sites), down twinkles go by the alternate name of "squid fingers".[12]

- Thumbs up, neutral, or thumbs down - Some locations use the thumbs signal, in a nonviolent show of approval, neutrality, or disapproval.

- Direct response is both hands moving alternately front to back on each side of the head and directed at an individual. Direct response indicates that critical information was missing from something that was just said.

- Clarifying question is a single hand formed in the shape of a $C$. Clarifying question means that someone has a question that needs to be answered before that person can vote on an issue.

- Point of process is a triangle formed by two hands with the index fingers touching and the thumbs touching to form a triangle shape. Point of process means that the conversation has strayed from the original topic.

- Wrap it up is both hands moved in a circular motion about each other. It means that the speaker should make his or her points and finish speaking.

- $\quad$ Raise the roof is both hands with palms facing up being moved up and down above shoulder level. Raise the roof means to speak up.

- Hard block is holding arms up and crossed. This indicates a firm opposition to the proposal, a break from the consensus that cannot be supported by this individual.

- Twinkles and down twinkles are used to take "temperature checks." They help the group have an indication if a group is getting close to consensus. Twinkles are also known as "sparkle" or "spirit fingers."

- $\quad A$ Little Heart, using first and second fingers from both hands, can be used to signal affection, to announce there is love here.

"This kind of sign-language decision-making is a new staple of left-wing protests. The gestures were popularized in 2007 by European groups like Climate Camp, Seeds for Change, and UK Uncut, but they were showing up in protest manuals as early as 1994" (Klein, 2012).

Facilitators work in teams, including a time keeper, a stack taker, a stack meter (helps them see if what they are offering their comment in the right category), support (other facilitators are there who can field questions), a vibe checker (someone who helps defuse things if it gets too heated so it can be more conducive for communication). The vibe checker may voice reminders about goals held in common, such as deep listening to one another, about how discussants are 
on the same side, and about how participants can take a breath and a stretch to facilitate their patience in hanging into the process. They are careful not to target or shame anyone, knowing that this can backfire on the process.

A key feature of Occupy deliberations is horizontalidad, horizontalism, a term first used in Argentina in 2001 in the face of its economic crisis. This term has spread widely to places such as Spain, Greece, and to the Occupy Movement in the U.S. Marina Sitrin, editor of Horizontalism: Voices of Popular Power in Argentina, and part of the General Assembly that helped to organize Occupy Wallstreet has studied the use of horizontalism in current social movements around the globe. Turning to each other instead of to any governmental agency, Argentines organized themselves into popular assemblies in their neighborhoods. The unemployed organized themselves into general assemblies, as did workers displaced from closed factories. They sought new ways of anti-authoritarian and anti-hierarchical selforganizing to take on the functions that had been abandoned by business owners and the government. Horizontalism emphasizes the importance of efforts to communicate outside of vertical or hierarchical power structures. It is concerned with the inclusive practices of direct or participatory democracy and the building of consensus. The practice of horizontalidad by its very difference implies a critique of and a rupture with practices where the many are subjected to the decisions by a powerful few. Instead, people meet to discuss a situation or concern. They listen closely to each other, taking turns speaking.

Horizontalidad is seen as a tool as well as a goal (Sitrin, 2012). In order for relationships to become free of the structures of capitalism and hierarchy, people begin in the present to relate differently to one another. Horizontalidad is a possibility available to us in any moment. It involves a re-orientation away from traditional ways of exercising power over others, and instead requires that we stand alongside others, creating together relationships that are graced by inclusivity, deep listening, and the communal discernment required by efforts at consensus. Consensus does not mean everyone agrees on all items of a plan or situation, but that rather an agreement has been forged that has considered where there is disagreement, listening in to minority positions, and seeking common ground that members can affirm, and not stand in the way of. Not all consensus situations are equal, as at times differences are breezed over and the group may be steered to a consensus that is hardly deep and that will then probably be difficult to execute over time. The goal, however, is a durable consensus, strengthened by the care with which it has been constructed.

Sitrin has been impressed with not only how widely horizontalidad has spread, but how organically it has emerged spontaneously in many different locations as people confront the pernicious effects of neoliberal capitalism. It makes sense that as people acknowledge that the solutions they need cannot come from the state, they orient toward each other.

[Th]e crux of the politics is that the point of reference is not above..., it is not to the state; instead it is across. It involves looking to one another in horizontal ways. And from that vantage point tactics and strategies are decided. (Sitrin, 2012, p. 62).

The first time I saw this mode of autonomous self-organization in clear action was in Quaker communities which use consensus as a common practice. My next exposure was in Chiapas in the Zapatista communities (Watkins, 2012). Many of the indigenous communities in southern Mexico decided to create together a system of self-governance. They acknowledge the state 
and its forms of governance, but they assert their right to self-governance. In this spirit of selfgovernance and self-determination, the communities have created their own schools, healthcare, cooperative farming, weaving, and other ventures. There are leaders who meet together to discern governance, but these leaders are rotating. They are representatives from the local communities. Leadership functions rotate among people, such that leadership is not experienced as vertical and exclusionary, but as a horizontal responsibility that is shared over time. Leadership is achieved through conversation with others, not by decision by a single person. Rather than continuing to demand needed things from the federal and state government, the communities are striving to develop the infrastructure to meet many of their own needs. To do so they are creating forms of relationship that are less corrupted by vertical hierarchies of power that do not hold the good of the people at the heart of their concern.

The orientation of the members of the Occupy Movement has been less focused on making demands of others, than it has been on trying to manifest themselves ways of being together that are radically different from the hierarchies we are used to. Both Paulo Freire and the Occupiers fear that unless forms of participatory praxis are in place, those who claim to be liberating others, are merely substituting themselves for leaders who have unjustly claimed authority and power over the majorities. Thus Occupy must begin and proceed differently.

We can think of Occupy as a decolonizing movement. Instead of striving to take over others' places in order to own them oneself, as happened during and since the Enclosure Movement, Occupy seeks to liberate privatized places of exclusion and return them to the majorities. Territory is seized to be released for the common good, not for the few against the many. Within the boundary of each liberated place, there is space for developing alternative systems of care (i.e., medical care, childcare, education, shelter), food security, communication, alternative economics (such as alternative currencies). These then serve as exemplars of the incarnated possibilities this precarious period offers us, and, indeed, demands of us.

Leadership in horizontalidad is inseparable from facilitation, for the facilitating leader's job is to help guard the space for participatory democratic group process. This opens the opportunity for each person to offer leadership through their individual experience, thought, and voice. Open space technologies are frequently employed to surface people's deepest concerns and to catalyze working relationships around them. All members of the movement are urged to study facilitation so that each person deeply understands the process and takes part in safeguarding it.

Leadership in OCCUPY will require taking the time to build modes of relationships where participants can glean the wisdom in contradictory perspectives, and creatively metabolize differences. Facilitating leaders will expect conflict and welcome what can be learned from it, while giving careful attention to avoid breakdowns in communication and relationship. At New York's Occupy Wall Street, nonviolent communication workshops are given regularly to foster the skills to collaborate and to de-escalate conflict when it threatens to rupture the relationships upon which the movement depends. Naomi Klein (2011), author of The Shock Doctrine, addressed Occupiers saying, "this time, let's treat each other as though we plan to work side by side in struggle for many, many years to come. Because the task before us requires nothing less." (p. 49). The leadership skills required by OCCUPY include the formation of solidarities with diverse groups and causes, such as the homeless, immigrants, union members, veterans, young men of color affected by the New York Police Department's" Stop and Frisk program," 
evicted homeowners, and others. They also involve inviting the arts, not only as a means of communication, but as a means of celebration, of drawing together the community in modes of joyful interdependence.

The message from Occupy is that we can each be a revolutionary leader among other revolutionary leaders in the small and large mosaics that are given to us in our day-to-day life. From the intrapsychic hosting of disparate inner voices, to the nonviolent communications needed in the home, from hosting democratic processes in the workplace that can include participatory budgeting, to the neighborhood block council and the occupation of the town square, the revolution is rooted in how we are with one another. Revolutionary leadership asks integrity from us, that we do not promote dialogue in one sphere only to close it down in others; that we do not seek the common good only in the small vessel of the family and amongst those similar to ourselves, but also in the workplace, on the other edge of our town, in the nation and abroad. Only a quest for this manner of integrity will begin to right our wrongs, for we know that we cannot afford to take literally the metaphor of the $99 \%$ against the $1 \%$. We are all implicated in the interlocking crises of democracy, of ecological demise, and spiraling violence that confront us.

The re-claiming of the Commons must go hand-in-hand with a process of psychic decolonization, where the received hierarchical roles and practices we have inherited are disrupted and thrown into question, including those concerning leadership. This is happening all over the world as autonomous communities develop from two and three to several hundred, to thousands. The Zapatistas imagine that one day these autonomous zones will be so numerous on earth that they will finally create a global shift. But recovering our commons proceeds small mosaic by small mosaic. The revolutionary leader of our time must be a facilitating leader. He and she must embrace humility, and engender hope that what is possible among a few here and more there, can gradually bloom widely and heartily in the fields we need to recover as our shared commons.

\section{Contact information:}

Mary Watkins, Ph.D.

Pacifica Graduate Institute

Email: maryw1415@aol.com

\section{Notes}

\footnotetext{
' This paper was written for Reimagining, Renewing, Reinventing Leadership, a public conference, Pacifica Graduate Institute, June 8-10, 2012, Santa Barbara, California.

ii "Instead of vibrant democratic public spheres, neoliberal capital creates what João Biehl calls 'zones of social abandonment,' the new domestic 'machineries of inscription and invisibility' that thrive on the energies of the unwanted, unbankable and unrecognized - a category that now includes more and more groups including students, women, immigrants, poor people of color and those who refuse to narrate themselves in the sphere of consumer culture" (Giroux, 2012).

iii Arendt likens this to the situation of America's founding fathers who used the phrase "a new order," "novus ordo seclorum."
} 
iv Snyder (1990) suggests that "common" from the Greek "ko" meaning together, and the Latin "munus" meaning service indicates "service performed for the community" (p. 34).

$\checkmark$ The open space movement of 1869 halted this practice, preserving the Epping Forest against the wishes of 14 manor lords (Snyder, 1990, p. 34). Nevertheless, because of the enclosures England has the least forest and wildlife of all nations of Europe.

${ }^{v i}$ For Freire domination was what characterizes our epoch, and liberation was the goal of revolution: a liberation that fostered the humanization and subjecthood of all. When Martin Luther King, Jr. began to critique the war in Vietnam, naming and denouncing the evil triplets running the United States-racism, capitalism, and militarism - he became a marked man. The same is true of Ignacio Martín-Baró, the Jesuit psychologist who named liberation psychology in El Salvador. During the Civil War in El Salvador, he used large scale public surveys to publicly present the suppressed realities of the people, contradicting the false reality propagated by political and economic elites. He was assassinated in 1989 by a CIA-trained Salvadoran death squad. Today we routinely hear of whistleblowers who are fired, blackballed, and even disappeared and murdered; indigenous leaders assassinated who attempt to protect the land from various forms of destruction; factory workers fired who seize machines to continue production; and young men like Sergeant Bradley Manning who risk their lives in the name of greater governmental transparency.

vii J. Helmiere (2012) calls this "activist imagination."

viii This reasoning is shared by the process of "Deep Democracy," articulated by Arnold Mindell (2002).

\section{References}

Arendt, H. (1971). The life of the mind. New York, NY: Harcourt.

Belenky, M. (1996). Public homeplaces: Nurturing the development of people, families, and communities. In N. Goldberger, J. Tarule, B. Clinchy, M. Belenky (eds.), Knowledge, difference, and power: Essays inspired by Women's Ways of Knowing. New York, NY: Basic Books.

Biehl, J. (2005). Vita: Life in a zone of abandonment. Berkeley, CA: University of California Press.

Collins, P. Hill (2000). Black feminist though: Knowledge, consciousness, and the politics of engagement. New York, NY: Routledge.

Freire, P. (1989/2008). Pedagogy of the oppressed. Boston, MA: Continuum.

Freire, P. \& Macedo, D. (1995). A dialogue: Culture, language and race. Harvard Educational Review, 65(3), 377-402.

Gadotti, M. (1994). Reading Paulo Freire: His life and work. Albany, NY: State University of New York.

Giroux, H. A. (2012). The Occupy Movement and the politics of educated hope. Truthout. Retrieved 6/1/12 from http://truth-out.org/opinion/item/9237-the-occupy-movementand-the-politics-of-educated-hope74 
Journal for Social Action in Counseling and Psychology

Graeber, D. (2004). Anarchism, Or the Revolutionary Movement of the Twenty-First Century. Znet. Retrieved 10/1/2012 from www.zcommunications.org/anarchism-or-therevolutionary-movement-of-the-twenty-first-century-by-david-graeber

Helmiere, J. (2012). The spirituality of Occupy. Tikkun, 272), 22-23.

Hoffman, G. K. (1997). An enemy is one whose story we have not heard. Retrieved 5/25/12 from http://newconversations.net/communication-skills-library-of-articles-and-teachingmaterials/gene-knudsen-hoffman-articles/an-enemy-is-one-whose-story-we-have-notheard/

Klein, A. (2011). Jazz hands and waggling fingers: How Occupy Wall Street makes decisions. New York Magazine. Retrieved 5/31/12 from http://nymag.com/daily/intel/2011/10/occupy_wall_street_hand_gestur.html

Klein, N. (2011). The most important thing in the world. In S. van Gelder and the staff of YES! Magazine (eds.), This changes everything: Occupy Wall Street and the 99\% Movement. San Francisco, CA.: Berrett-Kohler Publishers.

Mindell, A. (2002). The deep democracy of open forums: Practical steps to conflict prevention and resolution for the family, workplace, and world. Charlottesville, VA: Hampton Road Publishers.

Nhat Hanh, T. \& Berrigan, D. (2001). The raft is not the shore: Conversations toward a Buddhist-Christian awareness. Maryknoll, NY: Orbis Books.

Occupy Movement Needs Organization and Leadership. Retrieved 4/14/12 from http://northernstar.info/opinion/editorials/article_de63c1a0-10c7-11e1-ba950019bb30f31a.html

Sharp, G. (2005). Waging nonviolent struggle: $20^{\text {th }}$ century practice and $21^{\text {st }}$ century potential. Boston, MA: Extending Horizons Books.

Shepard, P. (1998). Coming home to the Pleistocene. Washington, D.C.: Island Press.

Shiva, V. (2002). Water wars: Privatization, pollution, and profit. Boston, MA: South End Press.

Sitrin, M. (2012, Spring). Horizontalidad and territory in the Occupy Movement. Tikkun, 32-33, 62-63.

Sharp, G. (2005). Waging nonviolent struggle. Boston, MA: Extending Horizons Books.

Snyder, G. (1990). The practice of the wild. New York, NY: North Point Press.

Watkins, M. (2012). Notes from a visit to several Zapatista Communities: Toward practices of nomadic identity and hybridity. Psychological Studies. 57(1), 1-8. 
Journal for Social Action in Counseling and Psychology

Watkins, M. \& Shulman, H. (2008). Toward psychologies of liberation. New York, NY: Palgrave Macmillan.

Wilkinson, R. \& Pickett, K. (2009). The spirit level: Why greater equality makes societies stronger. New York, NY: Bloomsbury Press. 
Journal for Social Action in Counseling and Psychology

\section{Appendix I: Consensus Decision Making}

[The following document was made available by a working group from OCCUPY Wall Street, San Miguel, MX]

Occupy Wall Street SMA uses consensus decision making for several reasons. Consensus is designed for every member's participation; for everyone to be heard; and all concerns to be addressed. It is inherently better to involve every person so that the decisions represent the will of the entire group and not just a few. More ideas and solutions are shared through consensus. The process helps everyone get what they need. This in turn creates more ease, cooperation, efficiency, and good will within the group in implementing the decisions and in building positive relationships among its members.

Consensus seeks the consent of the group and not necessarily the agreement of participants. It is collaborative for everyone contributes to a shared issue or proposal and shapes it into a decision that meets the concerns of all members as much as possible. It is cooperative for it asks us to strive to reach the best possible solution for the group and all its members, rather than competing for personal preferences. Everyone has equal input and participates.

Consensus does not have to be used for every decision within the group. Only those decisions that touch on the core values and mission of the group need consensus. For example, there does not need to be consensus for setting up the next meeting date. The larger group can delegate decision making (once trust has been established) to committees and subgroups.

\section{Roles}

Facilitator: The main responsibility of the Facilitator is keeping the focus on the original topic(s), moving the group through the agenda on time, keeping the group within the consensus process and thinking around the entire group. The Facilitator does not take part in the discussion (see co-facilitator); but identifies areas of agreements and disagreements (which pushes the discussion further); can suggest go-rounds, break out groups if needed; calls on speakers; articulates the sense of discussion, concerns and agreements and then proposes the heart of the decision.

Co-facilitator: Assists the Facilitator; takes over the facilitation if the Facilitator wants to enter into the discussion; assists in Listing or Stacking, if needed (Listing is those who want to speak, silently signal the Facilitator or the person doing the listing who then puts them on a list. Stacking is when a lot of people want to speak are asked to raise their hands and count off. People then speak in that order).

Timekeeper: Gives frequent updates and ample warning of short time. Keeps individual speakers from taking an excessive amount of time.

Guardian/Peacekeeper: Monitors the emotional climate, body language and non-verbal clues. Defuses emotional conflicts and maintains a climate free of intimidation and is also aware of potential power dynamics. This person can speak without being called on by the Facilitator. 
Journal for Social Action in Counseling and Psychology

Scribe/Note taker. Documents decisions, discussion and action points; writes down and keeps track of concerns during the discussion.

Participants Responsibility. The group as a whole is responsible for the decision and the decision belongs to the group. Consensus requires commitment to active cooperation, disciplined speaking and listening, respect for the contributions of every member, to actively participate and to stay on track with the issue being discussed. Everyone needs to be educated on the process.

A few Respectful Rules. No one speaks twice until everyone has spoken once (unless it's been opened up by the Facilitator and even then the Timekeeper or Facilitator can call a person on excessive time). Participants do not speak without being recognized by the Facilitator.

\section{Process}

1. Discussion of the item to identify opinions and information on the topic; to identify the general direction of the group and potential proposals for action. This discussion involves active listening and sharing of information.

2. Formation of a proposal based on the discussion.

3. Call for consensus using hand gestures. We use both hands up, fingers waving, for agreement and down for disagreement.

4. Identification and addressing concerns. Each dissenter presents her/his concerns, potentially starting another round of discussion to address or clarify the concern.

5. Modification of the proposal. The proposal is amended or rephrased in an attempt to address the concerns of the group.

\section{Call for consensus until a decision is made.}

Note: The order can be changed if the facilitator thinks it is best. For example, a discussion may happen and then address the concerns, then a proposal and then a call for consensus.

Dissent Options are available. A person may simply declare their reservations (are willing to let a motion pass) or stand aside (have a serious personal disagreement but are willing to let the motion pass). These can happen when the person doesn't have enough information to say agree or dissent and doesn't want to take the group time to have that discussion or when there is a reservation but they can live with the group decision.

A block happens when there is a moral objection so strong that they cannot live with the decision. [The Facilitator has the right to state to the group when she/he believes that a block is a power move or not a moral objection.]

It is encouraged for members to take a turn at the various roles to give the group diversity and to build a cadre of skilled members. 
Appendix II: Occupy Together Hand Signals

OCCUPY TOGETHER

HAND SIGNALS

\section{SPEAKING}

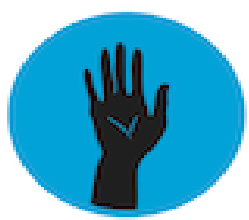

WANT
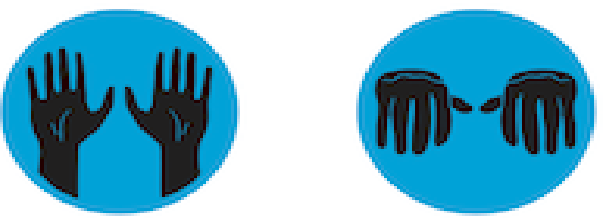

DQNT

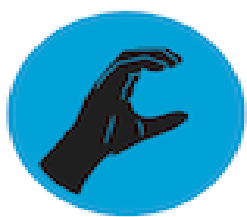

CLARIFY

\section{FEELING}

AGREE

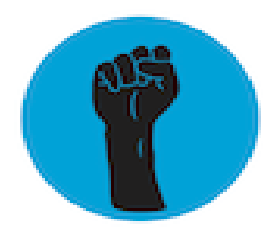

OPPOSE

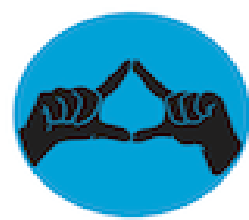

POINT OF
ORDER

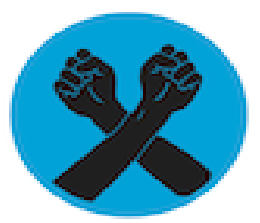

BLOCK 